\title{
EMOTIONAL SELF-PRESENTATION ON WHATSAPP: ANALYSIS OF THE PROFILE STATUS
}

\author{
Carmen Maíz-Arévalo \\ Complutense University of Madrid \\ Av. Séneca, 2, 28040 Madrid, Испания
}

\begin{abstract}
Self-presentation can be defined as "the process through which individuals communicate an image of themselves to others" (Yang and Brown, 2015: 404) and it is an essential part of human communication. Self-presentation has been widely studied both in face-to-face communication and online. Most online research, however, has focused on social networking sites, blogs, chatrooms, etc. while less attention has been paid to other online means of communication such as WhatsApp despite the growing importance of WhatsApp as a means of communication. The present paper aims to redress this imbalance by analysing self-presentation on WhatsApp; more specifically, by paying attention to emotional self-presentation in profile status. To that purpose, a corpus of 206 WhatsApp statuses was gathered in Spanish. Results show the existence of recurrent patterns connected to variables such as $\operatorname{sex}^{1}$ or age, which play a crucial role in determining the emotions users choose to display in their profile status.
\end{abstract}

Keywords: self-presentation, emotions, WhatsApp, Spanish

\section{INTRODUCTION}

Self-presentation can be defined as "the process through which individuals communicate an image of themselves to others" (Yang and Brown, 2015: 404). It is a dynamic process which develops along five major interconnected dimensions: intentionality, depth, positivity, authenticity and breadth (Kim and Dindia 2011, Yang and Brown 2015). Self-presentation can also trigger very emotional responses. For example, disclosing personal emotions can be positively valued by other members, who might reciprocally disclose their own emotions in return. However, disclosing too much can also have counter effects and lead to rejection by others both in face-to-face and online contexts (Altman and Taylor, 1973). Nowadays, with the increasing use of Internet to communicate, self-presentation takes place not only face-to-face but also digitally in the form of the profile or user status. As rightly argued by Attrill (2012), however, different settings will lead to different types of self-presentation. In the case of Facebook and WhatsApp, for example, the interface provides users with the possibility to offer semiautomatic self-disclosure by choosing from the available options. However, most users

1 The term "gender" has been purposefully avoided (and hence the use of "sex") given that its social components (e.g. the participants' sexual orientation and identification with gender independently of the biological sex) have not been considered in this preliminary study. Future research intends to zero in on social gender, for instance by means of interviews with participants so as to ascertain their gender adscription. 
prefer to edit their own status. This interface personalization is hence exploited by users to their own advantage so as to present themselves in a specific light (e.g. humorous, tender, sophisticated, wise, etc.) which makes them unique and different from the others. As Yus (2017: 78) points out:

An example is interface personalization, which in theory should generate an offset of positive effects in the way the user feels that he/she is treated as a unique individual whose specific preferences and usage patterns are attended to by the app. Users like to feel part of the group, network or community, but they also like to "stand out from the crowd," to feel unique in how they experience the app.

Indeed, most WhatsApp users tend to carefully select both the picture and status that other users will see whenever they exchange phone numbers. As evidence of the importance of the status, we just need to recall what happened last $24^{\text {th }}$ February 2017 when, coinciding with WhatsApp $8^{\text {th }}$ anniversary, its creators launched a new version of its "status". Rather than allowing users to include a short text next to their profile photo, the new version permitted to share a 24-hour status in a similar way to that of Snapchat. Users' massively negative response, however, forced WhatsApp to restore the past statuses just one month afterwards $\left(24^{\text {th }}\right.$ March 2017), after the web was flooded with complaints and queries about how to get back to the textual status ${ }^{2}$. This demonstrates that, far from being a frivolous matter, most users dearly value the opportunity these statuses provide for them as a self-presentation strategy. The aim of this paper is to delve into the kind of self-presentation users provide for others in their WhatsApp profile statuses, more specifically, whether Spanish WhatsApp users tend to reveal their personal emotions as a self-presentation strategy.

It is important to mention that the speaker's expression of emotions has been traditionally considered as an expressive speech act (Searle, 1969). However, given the heterogeneity of Searle's category of expressives, I shall follow Weigand's (2010: 166) more specific denomination of emotive acts, which she defines as statements "which focus on the speaker's emotional involvement [... such as] emotional affect or being overwhelmed by emotions" (emphasis in the original). Within self-dimension and its five interconnected dimensions (i.e. depth, breadth, authenticity, positivity and intentionality), emotional statuses are related to the dimensions of depth (i.e. level of intimacy of the presented information), and can also be related to positivity (in the case of positive emotions) and authenticity (i.e. degree to which the disclosed information accurately reflects reality). As for intentionality (i.e. the fact that the user is intentionally using this information to present him/herself), the expression of emotion is clearly intentional. Hence, the only dimension which does not play a significant role in the expression of emotion in WhatsApp statuses is breadth, understood as the frequency with which users display personal information (Yang and Brown 2015). Breadth, however, is directly linked to the new WhatsApp status, where users can share new personal information every 24 hours. The study of the new WhatsApp status might also open new avenues for future research, but it is unfortunately beyond the scope of the present study.

${ }^{2} \mathrm{http} / / /$ www.elconfidencial.com/tecnologia/2017-03-17/whatsapp-estados-texto-historiassnapchat_1350295/. 
Taking the above into account, I intend to answer the following research questions:

(i) Do WhatsApp users display emotional status (i.e. emotive speech acts) as a self-presentation strategy? If so, to what extent and in what frequency?

(ii) What are the linguistic realizations to express emotive speech acts (emotives henceforth) as a self-presentation strategy?

(iii) What kind of emotions are expressed by users when presenting themselves in WhatsApp?

(iv) Do the sociological variables of sex and age play a role in the use of emotives as a type of self-presentation strategy?

The rest of the paper is structured as follows; section two below briefly revises the literature on the concept of self-presentation and its study in digital communication ${ }^{3}$, with a special interest in studies focusing on WhatsApp. Section three describes the methodology, more specifically the criteria followed in the compilation of the corpus and its description. The fourth section discusses the findings and results in relation to the research questions before offering the conclusions in section five together with some pointers to future research or research already in progress.

\section{LITERATURE REVIEW}

Self-presentation has been widely studied both in face-to-face communication and online. Most online research, however, has focused on social networking sites (especially Facebook), blogs, chatrooms, etc. (cf. Bronstein 2012, García-Gómez 2010, Papacharissi 2011, van Dijck 2013, Zhao et al. 2008) while less attention has been paid to other online means of communication such as WhatsApp (Calero-Vaquera and Vigara 2014, Sultan 2014, Sánchez-Moya and Cruz-Moya 2015a, 2015b) despite its ever increasing popularity as a means of communication, with 1.2 billion worldwide users in January $2017^{4}$. This is probably why WhatsApp is increasingly attracting researchers' attention. Most studies up to now, however, have often adopted a sociological perspective, focusing on the social effects of WhatsApp amongst its users (Church \& Oliveira 2013, Soliman \& Salem 2014, Devi \& Tevera 2014, O’Hara et al. 2014, inter alia), with a special interest towards its effects on younger users, especially students (Bere 2012, Plana et al. 2013, Yeboah \& Ewur 2014, Ahad et al. 2014, Bouhnik \& Deshen 2014, Maniar and Modi 2014). This growing interest has also given rise to methodological concerns on data collection (e.g. Vela Delfa and Cantamutto 2016) and medical consequences related to the overuse of the app (cf. Montag et al. 2015).

3 Traditionally, the term computer-mediated communication (shortened as CMC) has been employed. However, this term no longer represents the kind of communication that may take place using other devices such as Smartphones or tablets. For this reason, digital discourse and digital communication are increasingly being used.

${ }^{4}$ According to the web Statista (https://www.statista.com/statistics/260819/number-of-monthlyactive-whatsapp-users/), WhatsApp had a thousand two hundred million active users in January 2017, which makes it the most widely used mobile messaging app worldwide (together with Facebook Messenger). 
WhatsApp also offers undeniable breeding ground for linguistic research, even if still under researched. As Calero Vaquera (2015: 112) points out, "WhatsApp interests us as linguists since it has become one more witness of human ability to adapt and colonize communicative competence in any channel" (my translation). This interest has more recently been also emphasized by Yus (2017: 75), who states that "WA [...], immensely popular nowadays and exhibiting interesting interface evolutions for a pragmatic analysis" (my emphasis).

More recently, there have emerged some studies that adopt a linguistic perspective, either discursive or pragmatic (or a combination of both) with a special interest in the multimodal $^{5}$ nature of WhatsApp (cf. da Fonte and Caiado 2014) or its use of typographical variation like textese (cf. Sánchez-Moya and Cruz-Moya, 2015a). Calero Vaquera (2015) provides a seminal study on the discursive similarities and differences between WhatsApp, Messenger and SMS, highlighting their hybrid and multimodal nature, especially given by the use of emoticons. Her study offers an interesting set of discursive features, which are subdivided into extra-textual, intra-textual and para-textual characteristics. However, in contrast to the current study, Calero Vaquera's does not offer a corpus analysis of naturally produced data but it is more an overview of WhatsApp characteristics, useful as a departing point for more detailed research. More recently, Yus' (2017) study focuses on the app from a relevance-theoretic approach, emphasizing the relevantly positive effects of its use to boost phatic talk. Most of these studies, however, have focused on WhatsApp either in general terms or on the "conversations" held by its users. Less attention has been paid to how users choose language to present themselves to others through the 139-character blank where "WhatsApp users are prompted to write any message in order to complete their profile information" (SánchezMoya and Cruz-Moya 2015b: 52), even if it highly contributes to the user's self-presentation.

In line with the present study, Sánchez-Moya and Cruz-Moya (2015b) also focus on the discursive analysis of 420 profile statuses by Spanish users, focusing on the age variable and the preference users have when editing their profile. On the whole, the authors provide a useful categorization based on the linguistic realization of the profiles, which they initially divide into automatically-generated statuses and self-generated ones. Automatically-generated statuses are those where users simply choose one of the statuses provided by default. In the case of WhatsApp, the default status is "Hey there! I'm using WhatsApp" but users may choose from the following range of 12 other default statuses, mostly showing their degree of availability ${ }^{6}$ (Available, Busy, I can't talk, only WhatsApp, Low bat, Only emergency calls, I'm sleeping) or places where they are located (At School, In the cinema, At work, At a meeting, In the gym). Self-generated statuses are those where users manually type a status of their own choice in the 139-blank

\footnotetext{
${ }^{5}$ Multimodality is here understood as the combination of two or mode modes (e.g. textual and visual) to communicate.

${ }^{6}$ Translation of the Spanish original. There are users who directly choose to write in English.
} 
character gap provided by the app. Within this macro-category, users may choose a purely verbal (or rather "textual") status, leave it blank, choose just emoji or a hybrid status where both emoji and text are employed. However useful the taxonomy offered, the authors do not delve into the content of such statuses or the pragmatic functions status profiling may perform. In the present study, I intend to partially fill this gap by focusing on a specific type of status and self-presentation: self-generated statuses where users display their personal emotions to others as a way to present themselves. Furthermore, focusing on the expression of emotions can help us observe whether the linguistic ${ }^{7}$ realization of emotions in digital discourse varies with respect to face-to-face communication (Derks et al. 2008) as well as to find out more about self-presentation patterns.

\section{METHODOLOGY}

The data used in the present study were gathered during a month, with the aid of two other WhatsApp users ${ }^{8}$ who kindly allowed her to use their contacts. Data was not elicited but naturally produced, and collected randomly to avoid any bias. However, to ensure both the ethics and validity of the data, four main criteria were taken into consideration. First, users below the age of 18 were not considered given their vulnerability as minors, focusing on five age spans: 20 years-old, 30 years-old, 40 years-old, 50 years-old and 60 years-old and +60 . Secondly, no personal data (proper names, photographs, etc.) that could identify the users in any sense were included to preserve their full privacy. All users were hence tagged according to their age (in their $20 \mathrm{~s}, 30 \mathrm{~s}$, etc.), which was provided by themselves or by the data-collectors. Third, to guarantee the validity of the gathered sample, the same amount of female and male users was gathered for each age group (see Table 1). Finally, the amount of users per age group was determined by the ratio of Spanish users of WhatsApp; that is, following the results published by secondary sources such as the webpage Statista ${ }^{9}$ and infogr.am ${ }^{10}$. According to Statista, the number of Spanish users of WhatsApp in February 2016 was led by the age group of 40-55, with $39 \%$ of users, closely followed by the $16-30$ age span $(36 \%)$ and the $31-39$ yearsold $(25 \%)$, as illustrated by Figure 1 .

In Statista's results, users of the last group (60s and $+60 \mathrm{~s})$ still did not have any representation, although this trend seems to have changed more recently, as shown by the results provided on WhatsApp users in Spain in January 2017, where the age range already includes 60-years old and more (even if in the last position), as illustrated by Figure 2.

${ }^{7}$ It is beyond the scope of this paper to focus on the profile photographs chosen by users. Future research is intended to contrast the kind of self-presentation strategy in the status with that of the chosen profile image.

${ }^{8}$ The author would like to express her gratitude to her husband, Carlos Carvajal, and friend, Yelena Petrovic, for their inestimable help in collecting the data. Without them, this study would not have been possible. All errors, however, remain exclusively my own.

${ }^{9} \mathrm{https} / /$ es.statista.com/estadisticas/576109/porcentaje-de-los-usuarios-de-whatsapp-en-espanaen-por-edad/.

${ }^{10} \mathrm{https} / / / \operatorname{infogr} . a m /$ uso_de_whatsapp_por_edades_en_espana_en_los_ultimos_seis_meses. 


\section{Distribución porcentual de los usuarios que utilizaron Whatsapp en España en 2016, por grupos de edad \\ $50 \%$}

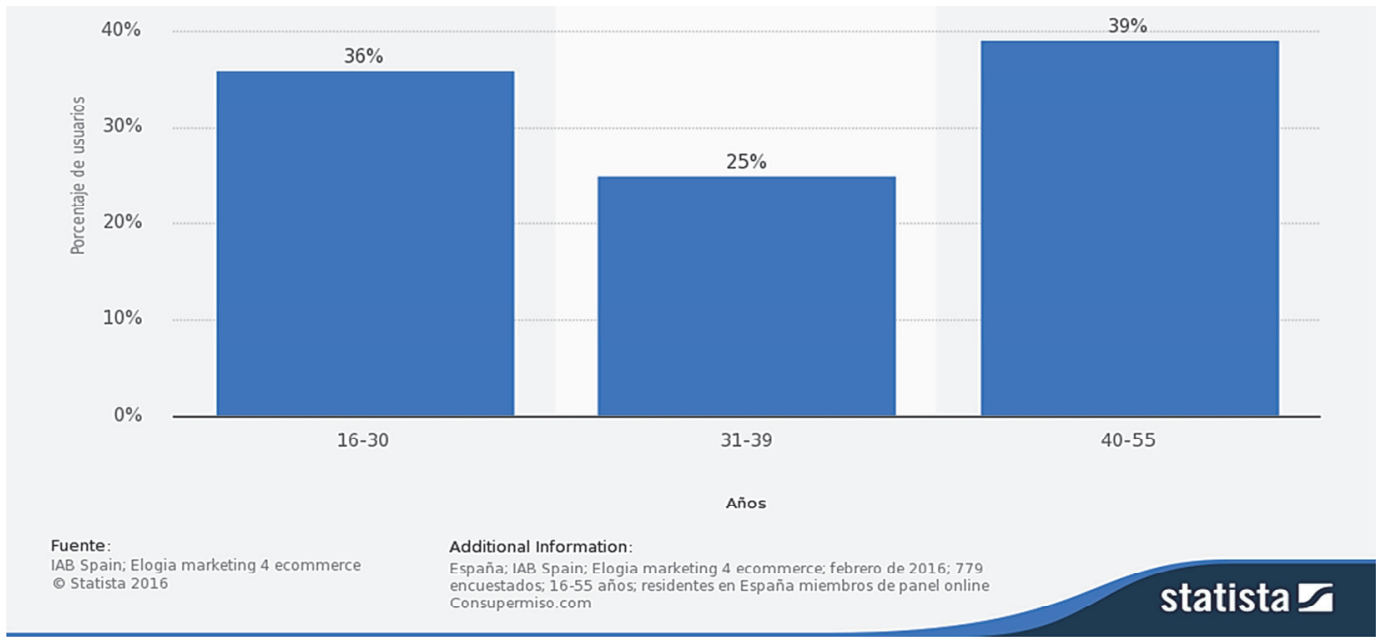

Figure 1. Distribution of users of WhatsApp in Spain according to age in 2016

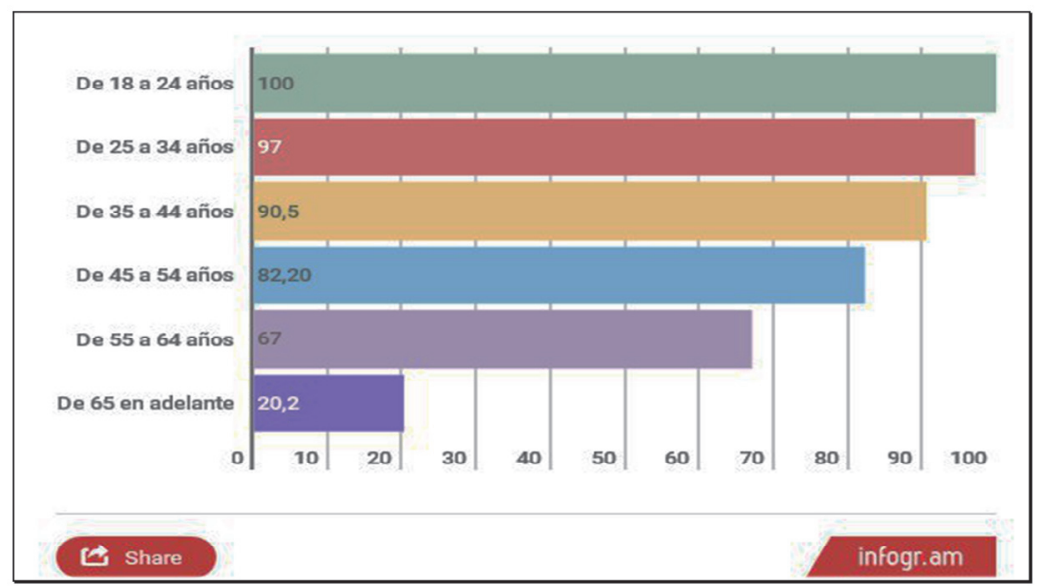

Figure 2. Distribution of users of WhatsApp in Spain according to age in January 2017

Thus, in the last months, the number of WhatsApp users belonging to the last population group (60s and over 60s) has slightly increased, entering the scene. Taking these secondary sources into consideration, the ratio of the present corpus was calculated per sex and age so as to ensure the calculated ratio represents that of the Spanish population using WhatsApp as closely as possible. The corpus thus gathered consist in 206 WhatsApp statuses produced by five age groups of both sexes in a proportion replicating the ratio of use provided by secondary sources (i.e. Statista and infogr.am). As in the secondary sources, the age groups leading the number of WhatsApp users are 40s and 50s, followed by $30 \mathrm{~s}$ and $20 \mathrm{~s}$, with the group of $60 \mathrm{~s}$ and +60 s occupying the lowest percentage, as illustrated by table 1 . 
Table 1

Age and sex of the subjects

\begin{tabular}{|l|c|c|c|c|}
\hline \multirow{2}{*}{ Age } & \multicolumn{2}{|c|}{ Sex } & \multirow{2}{*}{ Total $(\mathrm{n}=)$} & Ratio \\
\cline { 2 - 3 } & Female & Male & & \\
\hline $20 \mathrm{~s}$ & 12 & 12 & 24 & $11.65 \%$ \\
\hline $30 \mathrm{~s}$ & 16 & 16 & 32 & $15.53 \%$ \\
\hline $40 \mathrm{~s}$ & 37 & 37 & 74 & $35.92 \%$ \\
\hline $50 \mathrm{~s}$ & 26 & 26 & 52 & $25.24 \%$ \\
\hline $60 \mathrm{~s}(+60 \mathrm{~S})$ & 12 & 12 & 24 & $11.65 \%$ \\
\hline TOTAL & 103 & 103 & 206 & $100 \%$ \\
\hline
\end{tabular}

\section{DATA ANALYSIS AND DISCUSSION}

This section presents the findings together with their discussion regarding four aspects:

(i) The frequency of the use of emotive speech acts as a self-presentation strategy in WhatsApp statuses in relation to other strategies,

(ii) the linguistic realizations chosen by users to express their emotive speech acts,

(iii) the "content" of such emotive speech acts (i.e. what kind of emotions are users expressing),

(iv) and finally, the relationship between the variables of sex and age and the expression of emotive speech acts.

With respect to their frequency, a general overview at the statuses employed by users reveals that emotional statuses rank third (with 30 tokens out of 206, equivalent to a ratio of $14.56 \%$ ), with automatically generated statuses (e.g. "Hey there! I'm using WhatsApp") ranking first in the list $(31.55 \%)^{11}$. This low ranking (less than $15 \%$ of the total) coincides with the results obtained by Bronstein (2014) in her study of Hebrew Facebook users, where almost $70 \%$ of her participants admitted that the information they disclosed was rarely highly personal, as personal emotions indeed are.

Following Sánchez-Moya and Cruz-Moya (2015), WhatsApp profile statuses can be classified into different types according to their linguistic realization, as summed up by figure 3 .

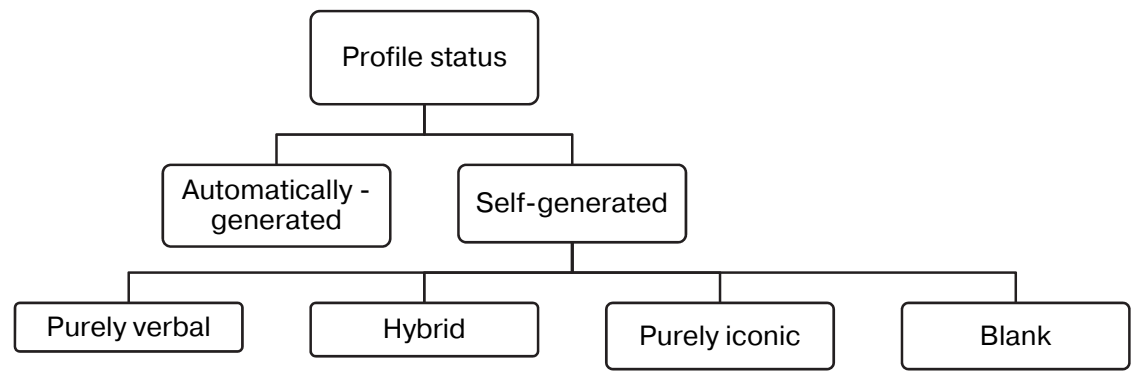

Figure 3. Types of profile status in WhatsApp according to linguistic realization (adapted from Sánchez-Moya and Cruz-Moya, 2015)

${ }^{11}$ It is beyond the scope of the current paper to analyse in detail the different self-presentation strategies performed by the participants. Future research intends to analyse these other types, which include the use of implicature (19.90\%), quotes (8.74\%), leaving the status blank (7.28\%), humour $(6.31 \%)$, inspirational messages $(4.85 \%)$, expressing a personality trait $(2.43 \%)$ and other realisations $(4.37 \%)$. 
According to these authors' classification, emotional statuses would belong to the category of self-generated statuses, since users edit the 139-character blank to display a personal emotion. Examples ${ }^{12}$ (1) to (3) illustrate this kind of self-presentation strategy:

(1) Me encanta mi hijo [I really like my son]

(2) Te quiero amor [I love you, my love]

(3)

As can be observed, users can choose to employ purely verbal statuses (example 1), hybrid ones, where text is used in combination with an emoji (example 2) and purely iconic ones like in example 3 . Hybrid realizations are slightly more frequent than the other two (see figure 4), which could be due to the fact that the emoji helps reinforce the verbal message in an iconic way, as illustrated by examples (4) and (5):

(4) La mala noticia es que el tiempo vuela, la buena es que tú eres el piloto

(5) True love

As for purely iconic statuses, where only emoji are employed, the repertoire is surprisingly limited despite the myriad of emoji available (one of the most popular affordances by WhatsApp). However, users seem to limit themselves to the rather basic ones and employ just smileys, hearts, kisses and an occasional unhappy face (see example 10):

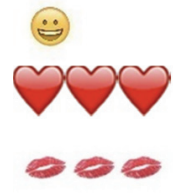

Smileys, however, still seem to the most prevalent emoji, even used in its typographically created version -i.e. :-) -being employed in more than $50 \%$ of the cases in which the status is purely iconic. Users thus seem to express their emotions in the three possible ways available (leaving the 139-character status blank is not an option in this case), in practically the same frequency:

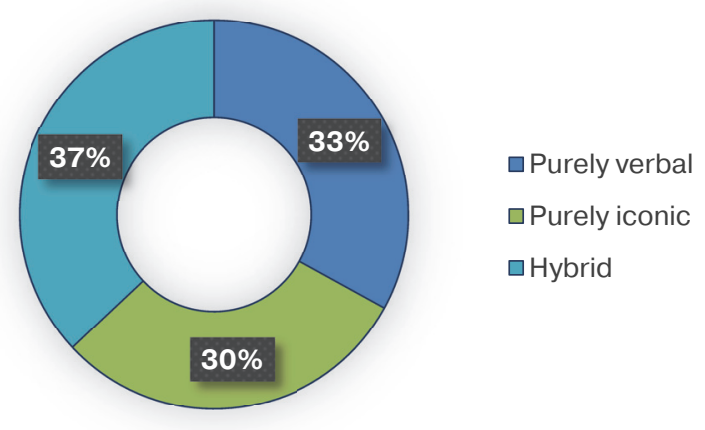

Fig. 4. Frequency of linguistic realizations of emotives

\footnotetext{
${ }^{12}$ Examples originally in Spanish are immediately accompanied by their translation in square brackets.
} 
More interesting, however, is the content or kind of emotions users choose to express when presenting themselves in their WhatsApp status. According to Plutchik (1997), there are eight basic emotions: fear, anger, sadness, joy, disgust, surprise, trust and anticipation (understood as the sense of looking forward positively to something which is going to happen). These basic emotions give rise to a complex myriad of other emotions, which Plutchik (1997) represents in what he terms the wheel of emotions (see figure 5), with the inner circle representing the strong expression of the basic emotions (in the middle circle) and the outer circle expressing their corresponding weaker version. Hence, joy is a basic positive emotion that becomes ecstasy when strongly felt and serenity in its mitigated version. Complex emotions like love are represented outside the wheel itself and partake of different emotions simultaneously (e.g. joy and trust).

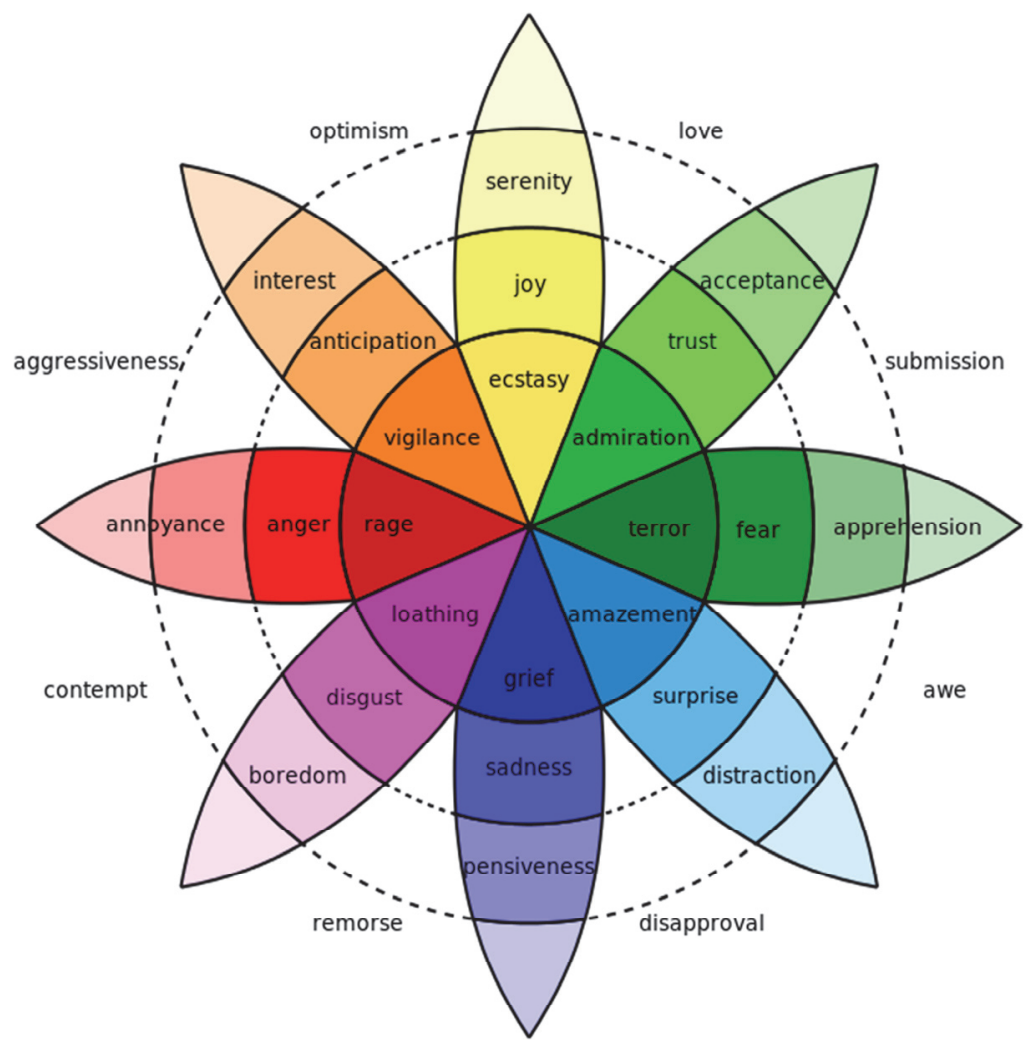

Figure 5. Plutchik's wheel of emotions

Plutchik's list of basic emotions roughly coincides with Ekman's (1992), although his taxonomy is much more complex than the latter's. Based on the recognition of facial expression, the latter argues in favour of six basic emotions: happiness, surprise, fear, sadness, anger and disgust (which can combine with contempt). In 1999, Ekman reconsidered his own list of basic emotions and expanded it to the following fifteen: amusement, anger, contempt, contentment, disgust, embarrassment, excitement, fear, guilt, pride, relief, sadness, satisfaction, sensory pleasure and shame. Ekman also considers love to be a complex compendium of different emotions, rather than an emotion per se. 
The analysis of the statuses reveals that positive emotions (both basic and complex) prevail over negative ones as illustrated by examples (9) and (10) where users express both annoyance and sadness in a purely verbal or iconic way, respectively:

(9) No me da la vida

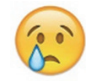

Positive emotions like joy or love pervade the statuses, which could be explained according to the Pollyanna hypothesis. According to the Pollyanna Hypothesis, "there is a universal human tendency to use evaluatively positive words $(\mathrm{E}+)$ more frequently and diversely than evaluatively negative words $\left(\mathrm{E}^{-}\right)$in communicating" (Boucher and Osgood 1969: 1). This also seems to apply to the dimension of positivity in self-presentation, which involves users presenting themselves in a positive light by enhancing their positive qualities, e.g. physical, social, psychological, etc. so as to project a likeable image of themselves rather than the opposite in the eyes of the others (Marwick 2011), as in examples (11) to (13) below:

$$
\text { Espiritu happy }
$$

[Happy spirit]

(12) Free

(13) I think I wanna stay alive and see if I can grow.

Positive emotives hence account for $87 \%$ of the sample (26 out of 30 tokens) with only two clearly negative emotives (examples 4 and 5 above) and other two which could be considered slightly ambivalent, since users seem to show an optimistic attitude against all odds (e.g. 14) or a fighting one which shows a mix of anger and vigilance ('aggressiveness' in Plutchik's wheel, as in 15):

(14) Enamorá de la vida aunque a veces duela [In love with life even if it hurts sometimes]

(15) En lucha por la tierra [Fighting for Earth]

Interestingly enough, however, the emotion that prevails is love for another person (usually the couple but also a relative like a son or daughter), which amounts to practically half the occurrences ( $43 \%$ of the tokens). However, telling other people about their love for others is not only a way of "showing" a positive side of the self but also of users implicitly presenting themselves as a socially functional persona (Zhao et al. 2008). Examples (16) to (17) illustrate this case, with user in (17) referring to her newly born baby and user in (18) referring to her one-year old daughter (with whom she also appears in the profile picture):

(16) Utterly in love

(17) $\bigcirc$ te requete quiero mi muñeco $\bigcirc$ [I absolutely love you, my doll]

(18) Siempre juntitas oe [Always together]

The last aspect of the analysis will focus on the variables of sex and age in the use of emotives as a self-presentation strategy. In this respect, it is interesting to point out that female users clearly outnumber their male counterparts in the expression of emotion to present themselves, with $83 \%$ of the tokens being produced by female par- 
ticipants as opposed to $17 \%$ by the male ones. This tendency seems to reinforce the sociocultural stereotype that "women are more emotional than men", based not on biological factors but rather on gender socialization (see note 2), as rightly argued by Lalama (2003). Hence, these female users may be expressing emotives so as to play the gender role expected from them. In a similar way, the male participants in the sample rarely express their love for others (except in the case of example (1)). Curiously enough, this participant has also asked for a paternity leave and is socially very conscious of gender equality, which might also have influenced why he chooses to present himself as a lovingly father. The other male participants, however, seem more prone to stick (maybe unconsciously) to the sociocultural gender stereotype, expressing aggression (example 15), pride as in (19) below, where the user refers to his abilities in a video game, or the user can also resort to a purely iconic status like in (20):

(19) Orgullo de tron $\square$ [Tron ${ }^{13}$ 's pride]

(20) :-)

The question that raises is whether age is as influential as sex in the use of emotive self-presentations in WhatsApp. Prior research has shown that age seems to play a core role in the amount and quality of personal information users may display, with younger users disclosing highly personal information more often on Facebook, blogs, etc. (Bronstein 2014, García-Gómez 2010). Age has also been shown to influence the kind of profile status chosen to be displayed in WhatsApp, with older users resorting to automatically-generated statuses much more often than younger users (Sánchez-Moya and Cruz-Moya 2015b).

As already pointed out (see fig. 1), the age group leading the use of WhatsApp in Spain is the 40-years-old (and those in their mid50s), followed by the groups in their 20s. The group in their 30s comes third and the group whose use of WhatsApp ranks lower is those in their 60s and over 60. This ratio has also been kept as closely as possible in the data-gathering (see table 1). Table 2 presents the different age groups and number of users employing emotives as a self-presentation strategy in the WhatsApp status $(n=30)$. The ratio of users is compared in the final column with the total ratio of the sample according to age group, to observe whether there are any differences with regard to age group in contrast with the total population under scrutiny $(n=206)$.

Table 2

Age and use of emotives in WhatsApp profile status

\begin{tabular}{|l|c|c|c|}
\hline \multicolumn{1}{|c|}{ Age group } & $\begin{array}{c}\text { No of users } \\
\text { (employing emotives) }\end{array}$ & Ratio & $\begin{array}{c}\text { TOTAL ratio } \\
(n=206)\end{array}$ \\
\hline $20 \mathrm{~s}$ & 5 & $16.7 \%$ & $11.65 \%$ \\
\hline $30 \mathrm{~s}$ & 7 & $23.3 \%$ & $15.53 \%$ \\
\hline $40 \mathrm{~s}$ & 11 & $36.7 \%$ & $35.92 \%$ \\
\hline $50 \mathrm{~s}$ & 6 & $20 \%$ & $25.24 \%$ \\
\hline $60 \mathrm{~s}$ (and +60s) & 1 & $3.3 \%$ & $11.65 \%$ \\
\hline TOTAL & 30 & $100 \%$ & $\mathbf{1 0 0 \%}$ \\
\hline
\end{tabular}

13 Tron refers to the homonymous science fiction film of 1982 and has now evolved into a video game. 
As shown in Table 2, younger users (especially those in their 20s and 30s) are more prone to perform an emotive speech act as a self-presentation strategy, with a difference of 5 and 7.7 points respectively between their total age group under analysis. This difference barely reaches 1 point $(0.78)$ in the case of 40 year-old users, which shows that age seems to influence users when expressing more deep-seated emotions, with younger users opting to reveal them as a self-presentation strategy more often than older users. This also seems to be more noticeable in the case of the use of emoji, with adults normally being less keen on using them massively. The use of emoji by younger users is illustrated by examples (4) and (5) and (17) to (19) above and by examples (21) to (23) below, where users are all females below their 30s:

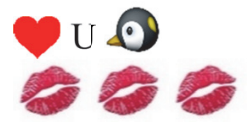

Thus, the older the age group, the lower the degree of emotional self-presentation, with the 50-years-old showing a negative difference of more than 5 points in contrast to the total population of their age and the $60 \mathrm{~s}$ and over $60 \mathrm{~s}$ simply resorting to automatically-generated statuses rather than to showing their emotions (with a different of -8.35 points). Figure 6 visually summarises the differences between each respective age group and the frequency with which each of them performs an emotive speech act as a self-presentation strategy:

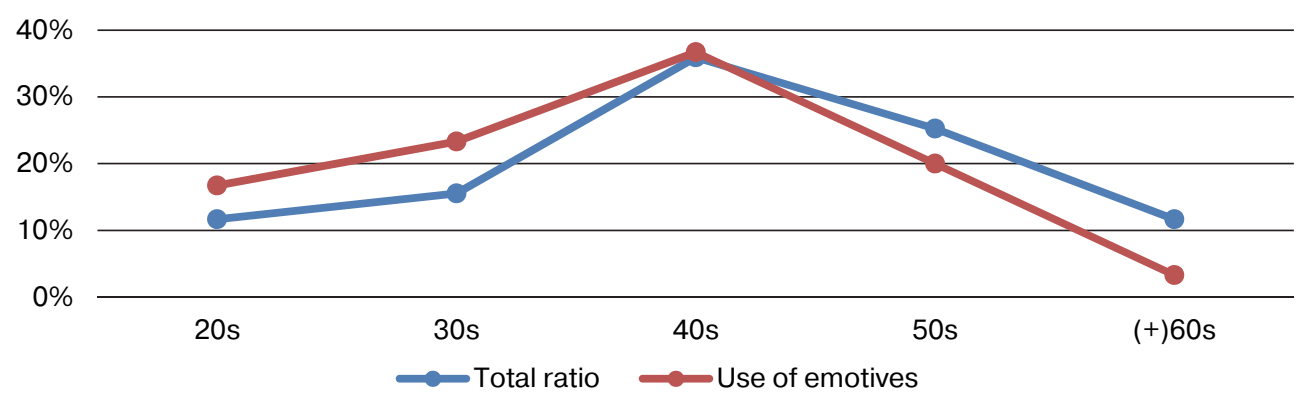

Figure 6. Use of emotive speech acts in relation to age

\section{CONCLUSIONS}

The present paper has attempted to provide an answer to four research questions, repeated here for the sake of clarity:

(i) Do WhatsApp users display emotional status (i.e. use emotives) as a selfpresentation strategy? If so, to what extent and in what frequency?

(ii) What are the linguistic realizations to express emotives as a self-presentation strategy?

(iii) What kind of emotions are expressed by users when presenting themselves in WhatsApp?

(iv) Do the sociological variables of sex and age play a role in the use of emotives as a type of self-presentation strategy? 
This concluding section will hence answer each of them in a summarised way, together with providing some pointers to future research. Thus, with respect to the first research question, the analysis of the results shows that the use of emotives in WhatsApp profile statuses is relatively limited in contrast to other self-presentation strategies like the use of implicature or the use of a default profile automatically generated by the app itself. However, it is still an option favoured on $14.56 \%$ of the occasions (30 out of the 206 analysed tokens).

Regarding the second question, emotives can be expressed by purely verbal statuses (e.g. utterly in love), purely iconic ones by means of emoji (e.g. (:) or by hybrid ones combining both text and emoticons. The latter are slightly more frequent, probably due to the fact that they allow for an enhancing of the message by visual means. The use of multimodality also helps to counterbalance the lack of body language present in most digital discourse, also known as disembodiment.

More interesting, however, is the kind of emotions expressed by users when presenting themselves in WhatsApp. It is observed that positive emotions dramatically outnumber negative ones, most likely due to the effect of the Pollyanna hypothesis. Likewise, the emotion that prevails is love, which amounts to practically half the occurrences (43\% of the tokens).

Finally, the fourth question focused upon the possible effect of the sociological variables of sex and age in the use of emotives as a type of self-presentation strategy. Results reveal that both variables seem to play a core role, with female users outnumbering male users in the use of emotive speech acts in their WhatsApp profile status, hence helping to strengthen the sociocultural gender stereotype that women are more emotional than men. Age also seems to have its say in the expression of emotions, with younger users (20s and 30s) employing emotives much more frequently than older generations (especially 50s and 60s). This results are in line with previous research, where youngsters were also shown to disclose more personal information than their elder counterparts (cf. Bronstein 2014).

This study has limited itself to the analysis of emotive speech acts as a self-presentation strategy but other strategies (e.g. the use of implicature, humour, etc.) also deserve scholarly attention, especially since they clearly outnumber the expression of personal emotions as self-presentation strategies. In fact, research in progress is tackling this aspect, also in relation to gender (see note 2 ) and age, as both seem to be crucial variables in how WhatsApp users choose to present themselves to the eyes of others. Furthermore, the study of profile photographs may help to shed some more light on selfpresentation, as previous research on Facebook has already shown (e.g. Hum et al. 2011). WhatsApp is indeed "happening" and opens up a research niche in linguistic studies that should not be neglected.

C Carmen Maíz Arévalo, 2018

\section{REFERENCES}

Ahad, Annie D. and Lim, Syamimi M. A. (2014). Convenience or nuisance? The 'WhatsApp' dilemma. Procedia, 155, 189-196.

Aharony, Noa (2015). What's App: a social capital perspective. Online Information Review, 39 (1), $26-42$. 
Anderson, K. E. (2016). Getting acquainted with social networks and apps: WhatsAppening with mobile instant messaging? Library Hi Tech News, 33(6), 11-15.

Altman, I., \& Taylor, D. (1973). Social Penetration: The Development of Interpersonal Relationships. New York: Holt, Rinehart, \& Winston.

Attrill, Alison (2012). Sharing only parts of me: Selective categorical self-disclosure across Internet arenas. International Journal of Internet Science, 7 (1), 55-77.

Bere, A. (2012). A comparative study of student experiences of ubiquitous learning via mobile devices and learner management systems at a South African university. Proceedings of the 14th Annual Conference on World Wide Web Applications. Cape Peninsula University of Technology, http://www.zaw3.co.za/index.php/ZA-WWW/2012/paper/viewFile/537/160.

Boucher, Jerry \& Osgood, Charles E. (1969). The Pollyanna hypothesis. Journal of Verbal Learning and Verbal Behavior, 8(1), $1-8$.

Bouhnik, D., \& Deshen, M. (2014). WhatsApp goes to school: Mobile instant messaging between teachers and students. Journal of Information Technology Education: Research, 13, 217-231.

Bronstein, J. (2012). Blogging motivations for Latin American bloggers: a uses and gratifications approach. In T. Dumova (ed.) Blogging in the global society. Hershey, PA: Information Science Reference, 200-215.

Bronstein, Jenny (2014). Creating possible selves: information disclosure behaviour on social networks. Information Research 19(1), 1-14.

Calero-Vaquera, M. L. \& Vigara Tauste, A. (2014). El discurso del WhatsApp: entre el Messenger y el SMS. Oralia, 17, 87-116.

Church, K., \& de Oliveira, R. (2013). What's up with WhatsApp?: comparing mobile instant messaging behaviors with traditional SMS. In Proceedings of the 15th international conference on Human-computer interaction with mobile devices and services, 352-361.

da Fonte, R., \& Caiado, R. (2014). Práticas discursivas multimodais no WhatsApp: uma análise verbovisual. Revista Desenredo 10(2), 475- 487.

Derks, D., Fischer, A. H., \& Bos, A. E. (2008). The role of emotion in computer-mediated communication: A review. Computers in Human Behavior, 24(3), 766-785.

Devi, T. S., \& Tevera, S. (2014). Use of social networking site in the University of Swaziland by the health science students: A Case study. Journal of Information Management, 1(1), 19-26.

Ekman, Paul (1992). Are there basic emotions? Psychological Review 99 (3): 550—553.

Ekman, Paul (1999). Basic emotions. In Dalgleish, Tim \& Mick Power (eds.) Handbook of Cognition and Emotion. New York: John Wiley \& Sons, 45-60.

García-Gómez, A. (2010). Disembodiment and cyberspace: Gendered discourses in female teenagers' personal information disclosure. Discourse \& Society 21(2): 135-160.

Hum, Noelle J., Perrin E. Chamberlin, Brittany L. Hambright, Anne C. Portwood, Amanda C. Schat and Jennifer L. Bevan (2011). A picture is worth a thousand words: A content analysis of Facebook profile photographs. Computers in Human Behavior 27(5), 1828-1833.

Kim, Jinsuk and Kathryn Dindia (2011). Online self-disclosure: A review of research. In: Kevin B. Wright and Lynne M. Webb (eds.), Computer-mediated Communication in Personal Relationships. New York: Peter Lang, 156-180.

Lalama, Christina (2004). Are women more emotional than men? Making Waves 2, 39—42.

Maniar, A., \& Modi, A. (2014). Educating WhatsApp generation through WhatsApp. ZENITH International Journal of Multidisciplinary Research 4(8), 23-38.

Marwick, Alice E. (2011). I tweet honestly, I tweet passionately: Twitter users, context collapse, and the imagined audience. New Media and Society 13(1), 114-133. 
Montag, C., Błaszkiewicz, K., Sariyska, R., Lachmann, B., Andone, I., Trendafilov, B., \& Markowetz, A. (2015). Smartphone usage in the 21st century: who is active on WhatsApp? Biomed Central research notes, 8(1), 331. [Available at https://bmcresnotes.biomedcentral.com/articles/ 10.1186/s13104-015-1280-z\#Bib1, accessed $7^{\text {th }}$ May 2017].

O’Hara, K., Massimi, M., Harper, R., Rubens, S., \& Morris, J. (2014). Everyday dwelling with WhatsApp. Proceedings of the 17th ACM conference on Computer supported cooperative work \& social computing. ACM, Baltimore, MD, USA, 1131-1142.

Papacharissi, Z. (ed.) (2011). A networked self: Identity, community, and culture on social network sites. London: Routledge.

Plana, M. G.-C., Escofet, M. G., Figueras, I. T., Gimeno, A., Appel, C., \& Hopkins, J. (2013). Improving learners' reading skills through instant short messages: a sample study using WhatsApp. Proceeding of WorldCall 2013-Call: Sustainability and Computer-Assisted Language Learning. University of Ulster, Glasgow, 80-84.

Plutchik, Robert (1997). The circumplex as a general model of the structure of emotions and personality. In Plutchik, Robert and H. R Conte (eds.) Circumplex models of personality and emotions. Washington, DC, US: American Psychological Association, 17- 45.

Sánchez-Moya, A. \& Cruz-Moya, O. (2015a). "Hey there! I am using WhatsApp": A Preliminary Study of Recurrent Discursive Realisations in a Corpus of WhatsApp Statuses. Procedia-Social and Behavioral Sciences, 212: 52-60.

Sánchez-Moya, A., \& Cruz-Moya, O. (2015b). Whatsapp, textese, and moral panics: discourse features and habits across two generations. Procedia-Social and Behavioral Sciences, 173, 300-306.

Soliman, D. A., \& Salem, M. S. (2014). Investigating intention to use mobile instant messenger: The influence of socialibility, self-expressiveness, and enjoyment. The Journal of American Academy of Business, 19 (2), 286-293.

Sultan, A. J. (2014). Addiction to mobile text messaging applications is nothing to "lol" about. The Social Science Journal, 51(1): 57-69.

Van Dijck, Teun (2013). 'You have one identity': performing the self on Facebook and LinkedIn. Media, Culture \& Society, 35(2), 199-215.

Vela Delfa, C. V., \& Cantamutto, L. (2016). De participante a observador: el método etnográfico en el análisis de las interacciones digitales de WhatsApp. Tonos Digital, 31, 1-22.

Yang, C. C., \& Brown, B. B. (2015). Online self-presentation on Facebook and self-development during the college transition. Journal of youth and adolescence, 45(2), 402-416.

Yeboah, J., \& Ewur, G.D. (2014). The impact of whatsApp messenger usage on students' performance in Tertiary Institutions in Ghana. Journal of Education and Practice, 5(6), 157-164.

Yus, Francisco (2017). Contextual constraints and non-propositional effects in WhatsApp communication. Journal of Pragmatics, 114, 66-86.

Zhao, Shanyang, Sherri Grasmuck, and Jason Martin (2008). Identity construction on Facebook: Digital empowerment in anchored relationships. Computers in Human Behavior, 24(5), 1816 1836.

Article history:

Received: 17 August 2017

Revised: 12 September 2017

Accepted: 15 September 2017

For citation:

Maíz Arévalo, Carmen (2018). Emotional Self-presentation on WhatsApp: Analysis of the Profile Status. Russian Journal of Linguistics, 22 (1), 144-160. doi 10.22363/2312-9182-2018-22-1144-160. 


\begin{abstract}
Bionote:
CARMEN MAÍZ-ARÉVALO is a professor of Pragmatics and English at the Department of English Language and Linguistics of Complutense University of Madrid, having obtained her $\mathrm{PhD}$ in English Linguistics in 2001. Her fields of interest are mainly pragmatics and intercultural pragmatics; more specifically, speech act theory and verbal (im)politeness in computer-mediated communication. Her most recent publications include articles published in Computer Assisted Language Learning (2017); the Journal of Politeness Research (2015), or the Journal of Pragmatics (2013 and 2012). She also acts as a reviewer for different journals such as the Journal of Pragmatics, GIST, Sage Open, or Modern Languages Journal. Contact information: e-mail: cmaizare@filol.ucm.es
\end{abstract}

\title{
FINANCE AND ACKNOWLEDGEMENTS:
}

This paper is part of the research project EMO-FUNDETT (Emotion and language at work: The discursive emotive/evaluative FUNction in DiffErent Texts and work conTexts), with reference FFI2013-47792-C2-1-P. This project is financed by the Spanish Ministry of Economy and Competition.

\section{ЭМОЦИОНАЛЬНАЯ САМОПРЕЗЕНТАЦИЯ В WНАTSAPP: АНАЛИЗ СТАТУСА ПРОФИЛЯ}

\author{
Кармен Маис-Аревало \\ Мадридский университет Комплутенсе \\ Av. Séneca, 2, 28040 Madrid, Испания
}

\begin{abstract}
Самопрезентацию можно определить как процесс передачи собственного имиджа другим (Yang and Brown, 2015: 404). Она составляет важную часть коммуникации и активно изучается исследователями как в сфере непосредственного межличностного, так и он-лайн общения. Однако основные исследования он-лайн самопрезентации базируются на материале социальных сетей, блогов, чатов и т.д., в то время как другим способам коммуникации, например WhatsApp, уделяется меньше внимания, несмотря на их возрастающее влияние. Цель данного исследования - восстановить баланс путем анализа самопрезентации на WhatsApp, в особенности ее эмоциональной составляющей в профиле статуса. Для достижения этой цели был проанализирован корпус из 206 статусов WhatsApp на испанском языке. Результаты показывают, что существуют определенные шаблоны, различающиеся в зависимости от пола и возраста и играющие важную роль в выборе эмоций, которые пользователи решают показать в профиле статуса.
\end{abstract}

Ключевые слова: самопрезентачия, эмочии, WhatsApp, испанский язык

\section{История статьи:}

Дата поступления в редакцию: 17 августа 2017

Дата принятия к печати: 15 сентябя 2017

Для цитирования:

Maíz Arévalo, Carmen (2018). Emotional Self-presentation on WhatsApp: Analysis of the Profile Status. Russian Journal of Linguistics, 22 (1), 144-160. doi 10.22363/2312-9182-201822-1-144-160. 


\section{Сведения об авторе:}

КАРМЕН МАИС-АРЕВАЛО - профессор прагматики и английского языка кафедры английского языка и лингвистики Мадридского университета Комплутенсе. Защитила докторскую диссертацию по английской лингвистике (2001 г.). Сфера ее основных интересов — прагматика и межкультурная прагматика, в частности, теория речевых актов и вербальная (не)вежливость в компьютерной коммуникации. Последние публикации представлены статьями, опубликованными в журналах Computer Assisted Language Learning (2017); The Journal of Politeness Research (2015), The Journal of Pragmatics (2013, 2012). Она также является рецензентом таких журналов, как GIST, The Journal of Pragmatics, Sage Open, Modern Languages Journal. Контактная информация: e-mail: cmaizare@filol.ucm.es

\section{ФИНАНСИРОВАНИЕ И БЛАГОДАРНОСТИ:}

Статья является частью исследовательского проекта EMO-FUNDETT (Эмоции и язык в действии: эмотивная оценка функций разных текстов и рабочих контекстов) за номером FFI201347792-С2-1-Р. Этот проект финансируется Министерством экономики и конкуренции Испании. 